\title{
History of Conservation of Shish Mahal in Lahore-Pakistan
}

\author{
M. Kamran ${ }^{1}$, M.Y. Awan, and S. Gulzar
}

\begin{abstract}
Lahore Fort is situated in north-west side of Lahore city. Lahore fort is an icon for national identity and symbol of both historical and legendry versions of the past. It preserves all styles of Mughal architecture. The fort has more than 20 large and small monuments, most of them are towards northern side. Shish Mahal is one of them and was built in 1631-1632 by Mughal Emperor Shah Jahan. Shish Mahal being most beautiful royal residence is also known as palace of mirrors. Shish Mahal has faced serious problems throughout the ages. Temperature changes, heavy rains, lightning and termite effect were the serious causes of decays for Shish Mahal. With the passage of time remedial works were proposed for Shish Mahal and were implemented accordingly. In 1991-92 serious cracks were observed in the ceiling. On the recommendations of experts the conservation of ceiling of Shish Mahal was carried out from 2003-2005. The paper will focus on history of conservation of Shish Mahal before partition and after independence. The paper will briefly discuss history of Shish Mahal, its architecture, conservation and detail of repair works. The paper draws conclusion for successful conservation to maintain the authenticity of historic monument as well as the failures in conservation works.
\end{abstract}

Keywords - Architecture, History of Conservation, Repair works, Shish Mahal

\section{INTRODUCTION}

The Fort is irregular in plan, which is 427 meters from east to west and 335 meters from north to south having a strong fortification walls which were built with small burnt bricks [1]. Access to the Fort through this strong fortification wall is through main gates located in the middle of East-West sides; and second access is in the North-West corner towards Badshahi Mosque.

This Fort represents a complete history of Mughal Architecture. The architecture of Emperor Akbar's period shows the extensive use of red sandstone and burnt bricks. Mostly, the same style was adopted during Jahangir's period. Shah Jahan and Aurangzeb used white marble and took Persian motives, pietradura and mosaic work. These were the main features added by Shah Jahan. The Fort has about 21 monuments in it; most of them are on the northern side.

\footnotetext{
${ }^{1}$ M. Kamran, Phd Scholar, School of Architecture and Planning, University of Management and Technology, Lahore

${ }^{2}$ M.Y. Awan, Professor, School of Architecture and Planning, University of Management and Technology, Lahore

${ }^{3}$ S. Gulzar, Associate Professor, School of Architecture and Planning, University of Management and Technology, Lahore
}

The most beautiful of them are Shish Mahal (Mirror Palace), Naulakha Pavilion, Diwan-e-Aam, Diwan-e-Khas, Jehangir's Quadrants, Moti Masjid, Masti and Alamgiri Gates etc [2]. Shish Mahal is the most prominent, beautiful and precious palace in Lahore Fort. It is situated in north-west side in the Fort. It is also known as palace of mirrors because of extensive use of mirror work over its walls and ceilings. It was formed as a harem (private) portion of the Fort. The hall was reserved for personal use by the imperial family [3]. Shish Mahal was listed as a protected monument under the Antiquities Act by Pakistan's Department of Archaeology in 1975[4].

Lahore Fort was protected under the Ancient Monuments Preservation Act 1904. An act to provide for the preservation of Ancient Monuments and objects of archaeological, historical or artistic interest[5]. Its historical and architectural significance was acknowledged and was listed in 1981 on the World Heritage List. The Fort was put on the list of World Heritage Sites in Danger on 2-12-2000 due to serious damage to the mirrored ceiling of the Shish Mahal [6].

The surrounding of Shish Mahal is as follows: on north there was circular road which is demolished for new developments. A project of landscaping is in progress there. Now the Fort, Badshahi Mosque \& Minar-e-Pakistan will share the same green area. On south there is walled city of Lahore, on east there is newly constructed road, Kashmiri gate and area of badami bagh Lahore. On west there is Badshahi Mosque of Lahore.

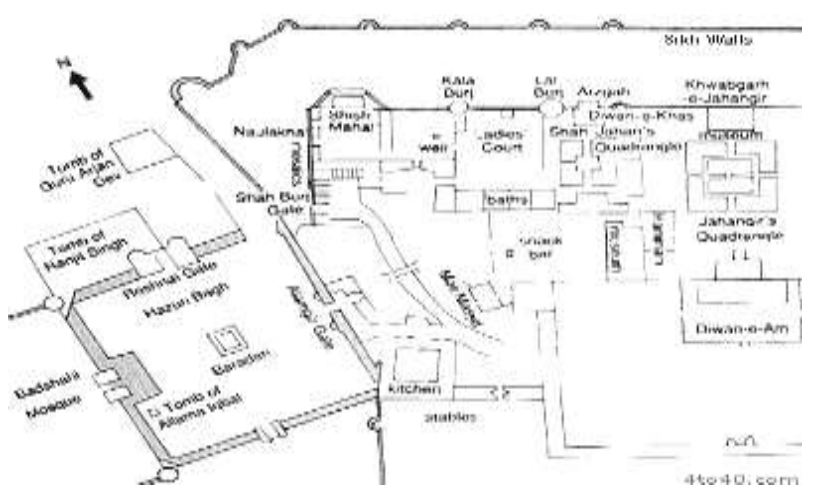

Figure 1: Map of Lahore Fort 


\section{METHDOLOGY}

"Shish Mahal" or the "Palace of Mirrors" was built by Shah Jahan for the residence of the empress when she stayed in Lahore [7]. Shish Mahal is one of unique palaces, containing beautifully executed inlayed stonework, glass mosaic work, and stucco tracery [8]. The finely carved marble net is used in openings and floor is paved with white marble [9].

On plan, it has a square shape, which opens towards an arcade of double pillars carrying multi-cusped arches inlaid with vine and flowers patterns in semi-precious stones.

A methodology is formulated for this study. Site surveys were conducted for selected Shish Mahal, Lahore Fort. The study focus on conservation, repairs, ceilings, structures, architecture, condition of masonry walls and materials used in shish Mahal which was constructed during Mughal Period. Several visits have been conducted to study history and conservation of Shish Mahal. A number of photographs of shish Mahal have been taken for the study. Some photographs are present in this article. Some other sources e.g thesis, journal articles, books, encyclopedias, discussions and photographs have been consulted for this study.

\section{ARCHITECTURAL STYLE OF SHISH MAHAL}

Shish Mahal has a rectangular main hall with several rooms on both sides as well as on the back side. From front it looks like a linear building. Main veranda of Shish Mahal is $26.5 \mathrm{ft}$ wide and $67.5 \mathrm{ft}$ long. At back there is $30.5 \mathrm{ft} x 15 \mathrm{ft}$ room and $15.5 \mathrm{ft} \times 15.5 \mathrm{ft}$ hexagonal chambers on its both sides. Overall area of Shish Mahal is in square form.

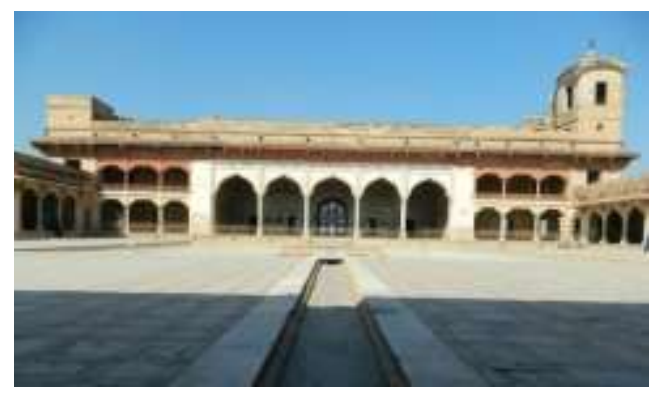

Figure 2: Front Elevation of Shish Mahal Lahore Fort

The roof of the central hall rises up to two storeys. Side rooms at front are double storeyed. Below Shish Mahal there are basement chambers. The façade of main varanda, comprising of five cusped marble arches supported by coupled columns, opens into the courtyard.

The main decorative features of Shish Mahal are as follows: The Aina Kari or mirror work with stucco tracery, Gild work (placing of pure gold), Pietra dura work, specially in the spandrels of the arches and on the bases of the double columns which carries multi-cusp arches [10].

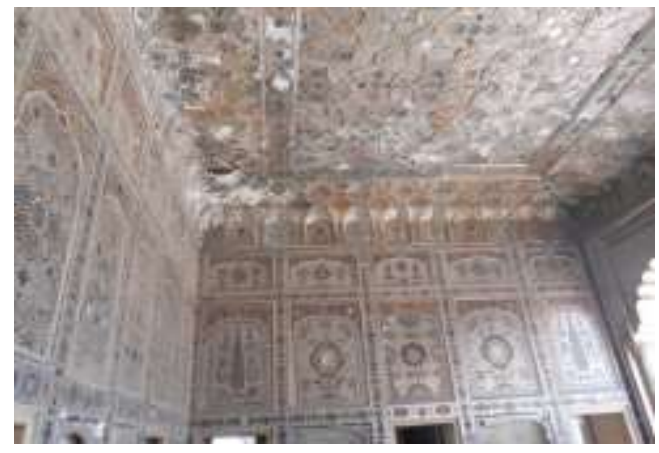

Figure 3: Mirror work in Main Varanda of Shish Mahal

The most important feature of this monument is the mirror mosaic work (ayina kari) applied on the walls and ceilings of all interior spaces [11]. This is inlay of precious stones into the white marble, Perforated marble screens (jalis) used as parapet walls as well as as for covering window openings, Use of Mughal lime plaster on side room, Paint work on ceiling curves (niches and naves). Masonry walls are made of burnt bricks which are 3 feet wide and have more width upto 15 feet in basement chambers.

The wall thickness in basement chambers varies from 12 feet to 15 feet. Basement roofs are in curved forms (semicircular). A variety of marble is used specially in courtyard like sang-e-badal, sang-e-abri and sang-e- musa [12]. Red sand stone is used at front of side rooms of main veranda of Shish Mahal. Wood work is used in ceilings of adjacent rooms of Shish Mahal.

There are two basements under Shish Mahal. The first basement was constructed by his father Jahangir. Shah Jahan constructed Shish Mahal and Naulakha Pavillion on the top of basement chambers.

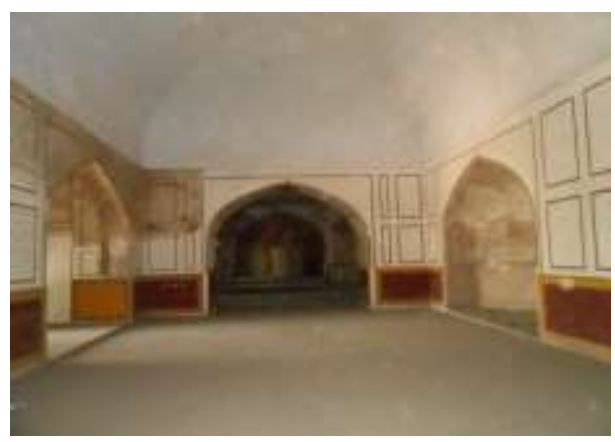

Figure 4: Basement Chambers towards West

Before construction of Shish Mahal there was need to stabilize the lower basement walls which were deteriorating rapidly. A proper \& stable solution was proposed and that was to add new heavy wall along with the old wall. This wall in also known as pictured wall and was built by Shah Jahan towards noth west sides of basements.

The dimensions of this wall are as follows:

Length $=1500$ feet

Height $=47$ to 55 feet

Width $=12$ feet

Its foundation was 15 feet deep and 25 feet wide [13]. 


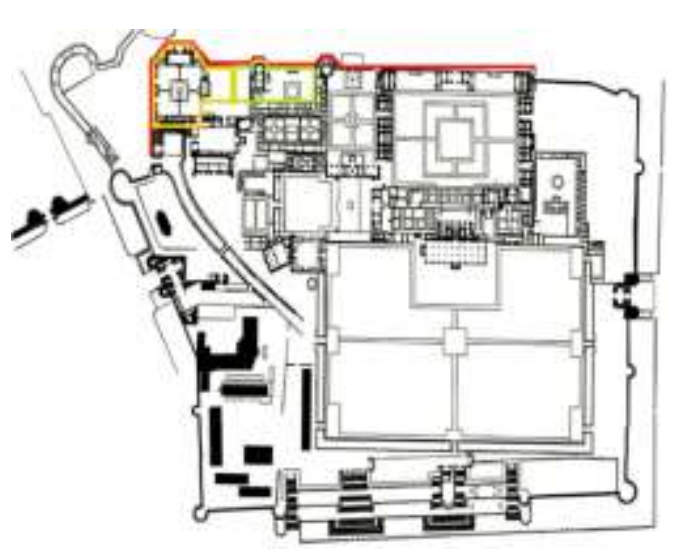

Figure 5: Map of Lahore Fort showing pictured wall in red, basement chambers of Shish Mahal in yellow, \& chambers under Kala Burj in green [14].

This pictured wall provided support to basement chambers like buttress controlling the outward pressure and also saved the eroded foundation of the fort.

Following materials were used during construction of Shish Mahal: Burnt bricks for walls, Marble for columns, windows and parapet walls, Stone pieces, Mughal lime plaster on walls, Paint work on walls, Wood work for roof of Shish Mahal, Mirror work for ceiling and walls, Lime in ceilings for pasting decorative features.

\section{HISTORY OF CONSERVATION}

Conservation of Shish Mahal is carried out throughout before partition and after independence.

\section{A. Pre-Partition}

During1904 and 1905 it was observed that the false ceiling of main front hall of Shish Mahal was affected due to heavy dead loads in form of additional rooms which were added on it during the Sikh and British period as shown in Figure 6. It was also badly affected by lightning in 1904 and the condition of the ceiling became very serious. An attempt was commenced by the Archaeology Survey of India for its strengthening. Part of the decorative plaster has already collapsed exposing two wooden beams in an advance stage of decay and it was further observed that most of these wooden beams were too rotten even to be support [15].

\section{B. Mirror Work}

Later on there were numerous losses in mirror work and much of the gilding of plaster had been loosed or damaged due to water seepage from roof top. During 1904-05 the Archaeological Survey of India took some major steps to restore and preserve the damaged structure of Shish Mahal. Although the problems of conserving the ceiling of Shish Mahal with all its mirror work from the collapse was actual difficult task but was successfully done at that time.

Concrete top roof was also removed to give relief to the wooden beams and ceiling [16] - [17].

\section{Ceiling of Main Veranda}

The ceiling of main veranda of Shish Mahal (Shah Burj) has been repaired more than once and still on. Since then this false ceiling remained under observation of the Department of Archaeology but the position is going bad day by day. At that time Department of Archaeology has been aware of the importance as well as magnitude of conserving, preserving and presenting the Lahore Fort as one of the leading monument in Pakistan.

The Government of Pakistan has done its best to preserve it by adopting the traditional and classical methods of conservation. Other than the routine maintenance and special repairs, some useful conservation work has been carried out under the Annual Development Programme.

\section{Post-Partition}

The first Master Plan was prepared in 1973 and the Department of Archaeology and Museums did its level best to maintain and keep up this unique palace of Mughal era. Maximum possible additions and alterations made in the past after the downfall of the Mughal dynasty which were serious threat to it were removed to regain the lost glory of the palace of mirrors. Its tessellated marble flooring in the main veranda and adjoining rooms have been restored according to the original pattern Naulakha pavilion, tasbih khana in the south west and south-east corner have also been attended for its flooring and marble screen to replace the Sikh period additions. The main courtyard of the Shish Mahal was also attended for its Sang-e-Badal flooring as per its requirement.

The roofs of the entire building were made water tightened along with kankar lime plaster applied to the wall etc. Some of the mirror work along with gilding work was carried out in the main veranda. The original niches/panels in one of the main verandah were also opened by removing the later period addition to exposure the paintings underneath [18].

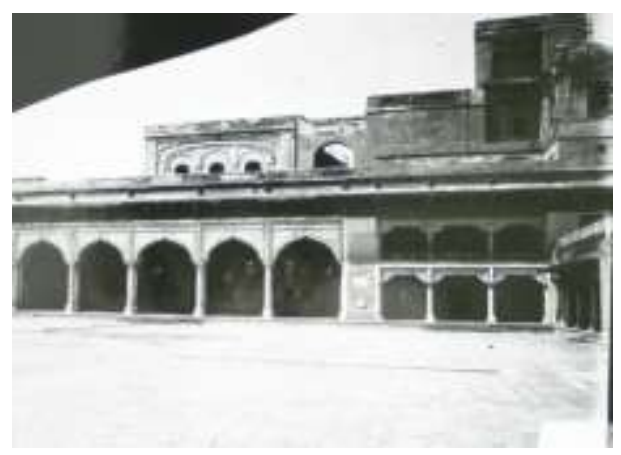

Figure 6: Additional Rooms Over Shish Mahal (Sikh Period Additions)

In 1991-92 some serious cracks in the ceiling were observed. This problem was getting more serious with the passage of time and for the immediate conservation and to avoid the serious danger the Department of Archaeology tried its level best to preserve such architectural jewels to maintain it for present and future generations.

The Federal Ministry of Culture constituted a Technical Committee in 1997 to advise there Department of Archaeology for arresting the further deterioration of the ceiling and to suggest remedial measures to revive its original grandeurs. 
Sir Bernard Feilden, Director Emeritus, ICCROM renowned conservation architect also visited Pakistan on the request of Government of Pakistan and UNESCO. In accordance with his recommendations, the Department of Archaeology and Museums propped up the sagged portion of ceiling on foam scaffolding on Hydraulic jacks temporarily and also an additional temporary roof has been provided to open the roof top of British period for study and Investigation purposes. Another mission from UNESCO visited Shish Mahal and submitted their investigations Report on various materials in 1999.

Against this backdrop and with the demolition of the unique hydraulic works of the Shalimar Gardens and Lahore Fort were placed on the list of World Heritage Site in Danger in December 2000. In response to a call for emergency assistance from the Government of Pakistan, UNESCO and the Government of Norway offered technical and financial support for the conservation and preservation of the Lahore Fort and the conservation of the Shish Mahal being taken up as top most priority.

The first and second meetings of experts in May and August 2003, on the conservation of Shish Mahal were a sincere move by UNESCO, the Norwegian Government and Government of Pakistan. That was to acknowledge the fact that the proficiency of architects, archaeological engineers, archaeological chemists, planners and other specialists in the field of conservation and exchange of other expertise provided a sustainable conservation strategy for Shish Mahal. On the recommendations of the experts the conservation of Shish Mahal ceiling was carried out from 2003-2005 [19].

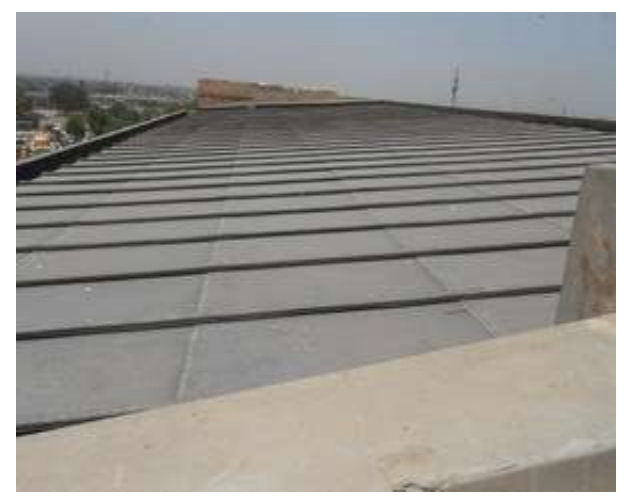

Figure 7: Roof Covered With copper Sheet

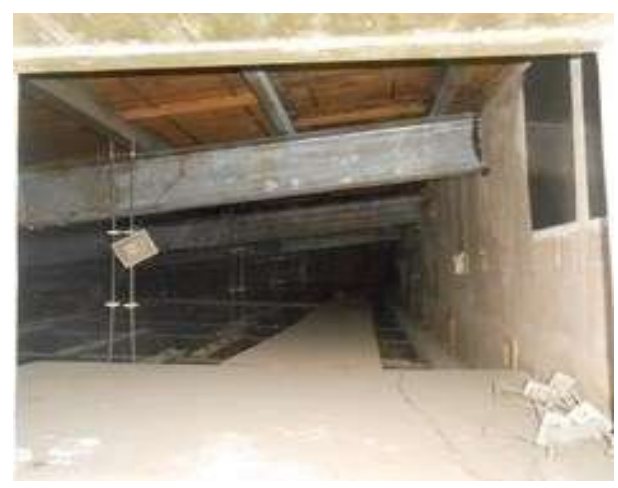

Figure 8: Double Roof with Supporting Hangers
The newly restored roof top of Shish Mahal covered with copper sheet urgently requires to be provided the Lightning proof arrangements to avoid any natural disaster like 1904 lightning incident.

\section{DETAIL OF REPAIR WORKS}

The restoration of mirror work and Stucco Tracery work at the Shish Mahal ceiling was carried out. This diligent work was of very deliberate nature and need full commitment and assimilation consists of first aid to the damaged portion of the decorative work.

The department of archaeology undertook conservation and restoration project with the financial assistance of NORAD and UNESCO [20].

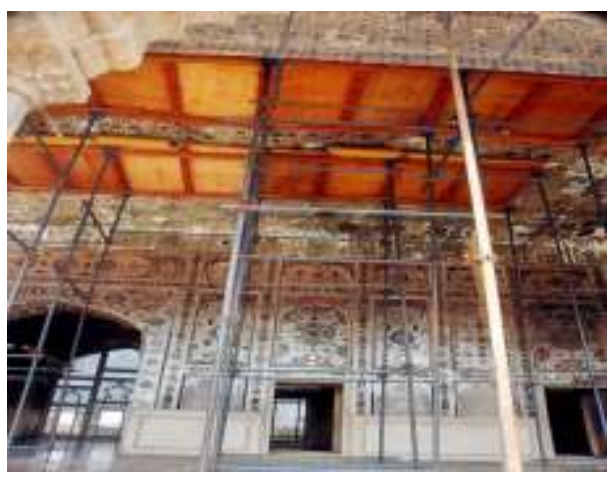

Figure 9: Ceiling Treatment

The cleaning of entire Shish Mahal was carried out including removal of grime, dirt and soiling is being undertaken by the female cleaning squad. The scientific cleaning of marble elements in the Shish Mahal.

In order to get available the trained hands for the execution of different decorative arts and crafts in the Shish Mahal, workshops for the training of various arts and crafts like Pietra Dura work, Stucco work, Fresco work and tile mosaic work were established in the courtyard of Shish Mahal. The Tarseem Bandi of ceiling of south eastern verandah of Shish Mahal was conserved including the replacement of deteriorated and worn-out wooden battens/beams. The Tarseen Bandi of ceiling of north-western verandah of mezzanine floor of Shish Mahal was conserved including the replacement of deteriorated and worn-out wooden battens/beams.

The roof of the Sikh period chambers on the northern side of Shish Mahal's present new roof was restored by the government of the Punjab in 2008. The Roof top and Tarseem bandi of the Aath dara outside Shish Mahal has also been restored by the Government of the Punjab in 2008. 


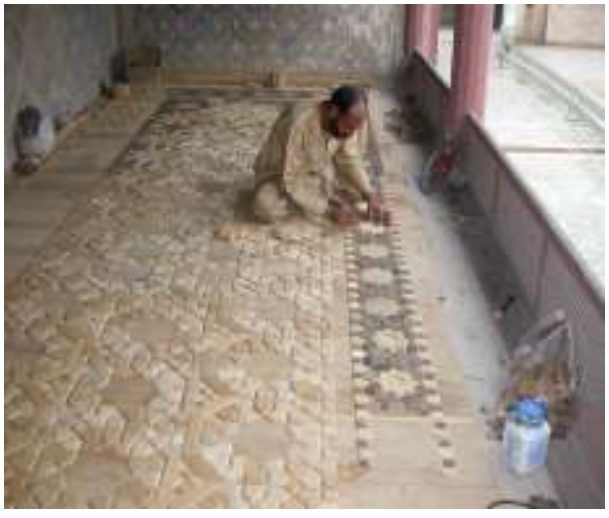

Figure 10: Inserting Floor Elements

The Façade of the Entrance gateway to fore court of the Shish Mahal has also been restored by the Punjab Archaeology in 2009. The Brick imitation and Fresco painting on Façade has also been done. The joints of the entire red sand floor around the Main Mirror hall and southern verandah were treated with stained lime mortar and marble Dado panels of summer and winter pavilions were preserved with new marble motives to check further deterioration. The roof top of North east pavilion was also restored and all the termite eaten beams were replaced by new ones after termite treatment.

\section{CONCLUSION}

There is need to develop an appropriate conservation plan for Shish Mahal keeping in view its original identity. Shish Mahal is the most precious monuments in the Fort. Systematic documentation of deterioration is required along with present condition surveys and history of interventions. There is also need to deploy a permanent restoration team for Shish Mahal and all structures in Lahore Fort need to be further explored for various other aspects.

Shortage of skilled craftsmen has been observed at conservation works of Shish Mahal. This shortage is due to limited conservation time to time. Because of these non-continuous conservation works most of the skilled workers left their professional skills and engaged to some other activities. It is highly recommended that permanent practical training of skilled craftsmen working on Shish Mahal and other historical monuments should be mandatory.

From the present study it is clear that conservation at Shish Mahal was not continuous. Conservation is an ongoing process; it should not be limited to the specific tasks but must be continuous simultaneously. It is suggested that comprehensive and balanced approach is needed for conservation projects. The precious heritage needs our attention for the long term survival. This research is an effort to initiate the first step based on technical data collection towards conservation of these irreplaceable assets.

\section{REFERENCES}

[1] Rauf, A. Structural Rehabilitation of Shish Mahal, Lahore Fort, Unpublished, MSc Thesis, University of Engineering and Technology, Lahore, 2006, pp-1.

[2] Khan, Shehar Bano (2004) Wither heritage? Dawn. 11 July. Retrieved 22 April 2008.

[3] Koch, Ebba (1997) Mughal Palace Gardens from Babur to Shah Jahan (1526-1648). Muqarnas, Vol. 14, pp. 151 http://dx.doi.org/10.2307/1523242

[4] Cultural week opens at Fort. Dawn. 16 August 2006. Retrieved 22 April 2008.

[5] The ancient monuments preservation act 1904.

[6] Cultural Tourism in Lahore and Peshawar, Government of Pakistan, United Nations Development Programme (UNDP) and United Nations, Educational, scientific and Cultural Organization (UNESCO).

[7] Khan, W.M. Lahore and its Important Monuments, department of archaeology Government of Pakistan, Lahore, 1959, pp-26.

[8] Lahore Fort Complex: Shish Mahal. Retrieved 21 April 2008.

[9] Dogar, Muhammad Aasim (1995) Splendour of Lahore Fort. Ilm Dost Publishers.

[10] Khan, W.M. Lahore and its Important Monuments, department of archaeology Government of Pakistan, Lahore, 1959, pp-27.

[11] Koch, Ebba. (1991). Mughl Architecture: An outline of $\mathrm{H}$ istory and Development (1526-1858). Munich: Prestel Verlog.

[12] Khan, W.M. Lahore and its Important Monuments, department of archaeology Government of Pakistan, Lahore, 1959, pp-28.

[13] Khan, R. Archaeology below Lahore Fort, UNESCO World Heritage Site, Pakistan: The Mughal Underground Chambers, For Global Heritage Fund Preservation Fellowship 2011.pp-4.

[14] Khan, R. Archaeology below Lahore Fort, UNESCO World Heritage Site, Pakistan: The Mughal Underground Chambers, For Global Heritage Fund Preservation Fellowship 2011.pp 7.

[15] Rauf, A. Structural Rehabilitation of Shish Mahal, Lahore Fort, Unpublished, MSc Thesis, University of Engineering and Technology, Lahore, 2006, pp-7-8.

[16] Khan (1997)

[17] Cultural week opens at Fort. Dawn. 16 August 2006. Retrieved 22 April 2008.

[18] Rogers P. and Lari Y. Lahore Fort Master Plan 2006-2011, Published by UNESCO Islamabad, 2006.

[19] Rogers P. and Lari Y. Lahore Fort Master Plan 2006-2011, Published by UNESCO Islamabad,2006.

[20] Rehman, A. (2011). "Conservation of Historic Monuments in Lahore: Lessons from Successes and Failures." Pak. J. Engg. \& Appl. Sci. Vol: 61-69.

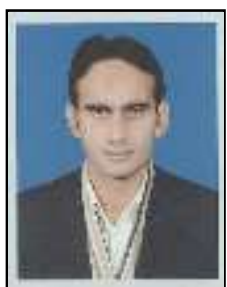

Bureau, Lahore
Muhammad Kamran

Place: Lahore, Pakistan

Date of Birth: 15 December, 1981

$\mathrm{PhD}$ Scholar University of Management and Technology Lahore.

Masters in Architecture from University of Management and Technology Lahore (2015).

BSc Architectural Engineering from University of Engineering and Technology Lahore. (2006)

Working as Design Manager in Engineering Design 